\title{
Some Proposed In-Service, or Supplementary, Training Programs
}

\author{
THE following three statements were presented at the Conference of Eastern College \\ 1 Librarians, Columbia University, Nov. 30, 1946.
}

\author{
By KEYES D. METCALF
}

\section{Suggestions for Training Librarians}

My assignment to help straighten out one phase of the library training problem in ten minutes is far beyond me. It would be just as far beyond me in ten hours! But in spite of the limitation, I am going to take a large part of my time to make some general comments before going on with such suggestions as I have in mind.

I. I think that we (and by we, I mean librarians in general) have been apt to blame our library schools too much and ourselves too little for the seeming lack of success in some phases of our library school training.

2. I think that the library schools, encouraged by the librarians, have tried to do too many different things in one year, and then consider that the graduate is ready for everything or anything. A basic course for the training of practically all librarians is a good idea in itself, if this basic course doesn't end matters, but we certainly have no right to think that anyone who has taken the basic course can do all kinds and varieties of library jobs acceptably without more training, either in library school or through "in-service" training.

3. I think we have failed to realize that a good cataloger or a good reference worker does not automatically become a good administrator.

With the above in mind, here are two propositions which it seems to me may help us to understand the situation:

I. It takes a different kind of natural ability to be an administrator than to be a cataloger or a reference worker.

2. Other things being equal, library training is a fine thing, but we must not forget that in the long run it is natural ability and willingness to work that count most, and a good untrained person will in time do better library work than a poorly endowed trained person.

Our first problem then is to get the right people into library work, and to give them the best possible basic training. But what can we do after the basic training in the way of preparing library administrators? Three methods have been used:

I. A second-year library school course specializing in administration. I have real doubt as to the success that has come from efforts of this kind.

2. The so-called sink-or-swim method where the librarian is simply put into an administrative job and sinks or swims. This is now common practice.

3. What is known as "in-service" training. Some of us have called it internship. This has been tried from time to time all over the country, and informally, but on a large scale, at the New York Public Library during the past twenty-five years with very considerable success.

There is a fourth method of which, it seems to me, we have failed to take full advantage. That is special training for administration, not in a library school, but in a university that is equipped to give it. This 
training might include: (a) courses in administration such as are found in the best university business schools and occasionally in graduate schools of education; (b) internship in a university library, combined with a seminar in library administration based on the work carried on in the internship.
If these two things are provided, after a man or woman has had basic library school training, in addition to a master's degree in a subject field, there should be a good prospect for a successful library administrator if the individual was well selected at the outset.

By RUDOLF HIRSCH and others

\section{University of Pennsylvania-In-Service Training Program ${ }^{1}$}

Convinced that the time is ripe for experimentation in library education based to some extent on theories expressed in recent critical writings, the University of Pennsylvania Library outlines in this paper its projected in-service training program. We have no thought of attempting to start a new library school, neither do we believe that proposals like ours will make library schools obsolete.

Among the specific considerations which have motivated us, we place first the present scarcity of librarians which, coupled with the inflationary trend of our economy, has raised beginners' salaries without proportionate increases to more experienced members of the profession. Such a discrepancy would be justified only if the basic qualifications and training of newcomers were superior to that of their predecessors. This, however, is, not the case. Since a proper balance in the salary scale of the entire staff is essential in order to retain professional satisfaction, either we have to work towards a proper balance between the salaries of new members of the profession and those of more seasoned members, or we have to attempt to apply standards to new recruits which will justify a higher scale of pay.

1 Paper presented at the Conference of Eastern College Librarians by Rudolf Hirsch; prepared jointly by Charles W. David, Dorothy Bemis, Arthur T. Ham. lin, and the speaker.
The second consideration which has influenced us is admittedly controversial. We, and, with us, many colleagues, believe that the three fundamental qualifications in librarianship are: proper attitude toward books, adequate knowledge of books, and clear understanding of the use of books. Admission to library schools in our era of mass education does not necessarily meet and perhaps cannot meet such specifications. Training is focused on techniques and is not such as to equip librarians to apply a qualitative judgment to the collecting, recording, and servicing of books. We realize the importance of technical aptitude, but we propose to supply technical training through a paid apprenticeship; we further propose to integrate this apprenticeship with an instructional program which will be developed around books and bibliography rather than around techniques, administration, or specialization. The teaching program of the University of Pennsylvania Library is empirical in parts only; it does not emphasize training for specific library operations. I should like to give a brief explanation for this departure from more generally accepted and more orthodox methods of library teaching.

We observe in almost all fields two conflicting trends: one toward greater specialization with a utilitarian outlook toward 